Howe, C. (2007). Sexual borderlands: Lesbian and gay migration, human rights, and the metropolitan community church. Sexuality Research \& Social Policy, 4(2), 88-106. http://doi.org/10.1525/srsp.2007.4.2.88

\title{
Sexual Borderlands: Lesbian and Gay Migration, Human Rights, and the Metropolitan Community Church
}

\author{
Cymene Howe
}

\begin{abstract}
This article considers several questions surrounding sexual migration, binational same-sex couples, legal precedent, and the role of religious communities in lesbian and gay migration to the United States. With theoretical aspects of human rights serving as a starting point, the article then moves to a consideration of the legal dynamics of migration, the history of U.S. (im)migration law in relation to lesbian and gay asylum claims, and the Uniting American Families Act (2005). Drawing from the concept of sexual migration, the article proposes that religious or spiritual communities may provide important networks and ideological resources for lesbian and gay migrants who subscribe to religious values, particularly in a context of politically incendiary claims surrounding homosexuality and immigration. The analysis centers on the Metropolitan Community Church (MCC), suggesting that with its socially legitimatized status, MCC may provide philosophical foundations necessary for effectively addressing human rights for lesbian and gay migrants.
\end{abstract}

Key words: sexuality; immigration; religion; law; binational couples 


\section{Love Crossing Borders}

Michael and Wuen-lin fell in love, they said, "within hours." Their correspondence began online, with Wuen-lin in Singapore and Michael in California. They met in person for the first time when Michael made the trip to Singapore; since then, they have experienced 8 years of affection for one another, as well as the challenges of being a same-sex binational couple (a couple in which the partners come from different countries). Michael, a White gay man, was "in hiding," he said, until he read Armistead Maupin's Tales of the City (1976). Then, he described:

My barriers were shattered...I was stuck in Bakersfield ${ }^{2}$ and I made a decision to commit to either Long Beach or San Francisco. Even though I had been afraid of San Francisco, from what I had heard in the media and what it meant to be gay there, I fell in love with the city after visiting and I made the choice to relocate.

Wuen-lin, who was born and raised in Singapore, identifies himself as Chinese. He describes being raised Taoist with, as he stated, Buddhism inside. Wuen-lin became a Christian at 13 years of age. Looking back, he describes that he accepted Christianity because he knew that he was gay then. "[Christianity] was a way of dealing with too much guilt...they offered a way out by saying that Jesus forgives of all your sins: Accept Christ and all will be forgiven...just pray harder and I will be straight or something." After completing a bachelor's degree at the University of Singapore, Wuen-lin came to the United States to be with Michael and to earn an MBA, "because that is the only way I could stay here."

Wuen-lin and Michael's story, although only one among many, demonstrates some of the challenges of [End Page 88] migration for same-sex binational couples; the role of religion in meeting those challenges; and the complexities of creating a home when faced with crossing borders, dealing with legal barriers, and living one's sexuality in places where it is not always safe or sanctioned to do so. Wuen-lin's belief in Jesus's forgiveness allowed him to imagine new possibilities for himself as part of a binational same-sex couple. Christianity was a legitimizing framework for his new sense of identity and, following his arrival in the United States, the Metropolitan Community Church (MCC) became an important spiritual and social support for both Wuen-lin and Michael as they worked through the challenges of Wuen-lin's migration and of being a binational gay couple.

Largely unknown to the general population - and even within the lesbian, gay, bisexual, and transgender (LGBT) community - gay and lesbian migrants confront a number of complex challenges as they cross national boundaries. Documented cases of queer ${ }^{3}$ migration experiences are relatively rare, and the ones that do exist are often less than positive. Historically, partners in

\footnotetext{
${ }^{1}$ The interview with Wuen-lin and Michael (both pseudonyms) was conducted by Lorrie Ranck in July 2003 as part of The Religion and Immigration Project (TRIP), directed by Lois Lorentzen at the University of San Francisco, with funding provided by the Pew Foundation.

${ }^{2}$ Bakersfield, a city in central Southern California, is considered by many to be socially conservative.

${ }^{3}$ In this article, I use the terms lesbian and gay - and, to a lesser extent, queer - to designate individuals in samesex affective and sexual relationships. Though these terms cannot fully provide the nuance required to capture same-sex relationships from a variety of cultures, I rely on these categories as a shorthand in this discussion. The term queer is used more advisedly in this discussion because, despite the popularity of queer identity among activists and (largely) urban and (largely) youth populations in the United States, many sexual minorities in the developing world hope to normalize their status rather than index their queer nonconformity. Finally, although many of the migration concerns covered here could be applicable to bisexual or transgender individuals or couples, I am not able to fully address those complexities here.
} 
binational same-sex couples and lesbian and gay migrants coming to or already in the United States had been reluctant to disclose their sexuality for fear of being "denied access" (Ranck, 2002, p. 373). Even though the agencies in charge have changed, the current situation is similar: Lesbian and gay migrants may fear revealing their sexual identity to Immigration and Customs Enforcement or U.S. Citizenship and Immigration Services officials. ${ }^{4}$ From the point of view of immigration authorities, migrants' involvement in an ongoing same-sex relationship would constitute a risk of their overstaying their visa, making them, in some cases, immediately deportable (Donayre, 2002).

This article examines some of the many dynamics surrounding migration for lesbians and gay men, binational couples, legal precedent, and human rights, as well as how religious communities such as MCC might function as advocacy resources. I argue that MCC's philosophical and epistemological foundations may be especially conducive to addressing the advocacy concerns surrounding migration for partners in same-sex binational couples. First, I wish to suggest that MCC has several conceptual resources and historical antecedents that might prove particularly adept at helping people move beyond the heteronuclear family paradigm that so prevails in immigration law and practice and has, historically, worked to the detriment of lesbian and gay migrants.

Second, I aim to show how MCC as a church — a religious, spiritual, or faith-based organization as opposed to a civil institution-may provide spiritual support for those immigrants who are inclined to attend it. Migration to a new country always involves a radical upheaval from home and is, therefore, a process that more often than not requires networks of social support. Just as family and kin networks have proven critical to nonlesbian and nongay migrants (Menjívar, 2000), the spiritual essentialism propounded by MCC may serve as an alternative for people who do not, because of their sexual identity, have the support of their natal kin networks. Given the volatile culture wars in the United States surrounding homosexuality and immigration policies, religious institutions with their socially sanctioned status may be able to draw upon social and spiritual legitimacy in ways that civil institutions may not. Although I do not want to imply that nonreligious organizations - such as Immigration Equality or Love Sees No Borders, both of which are dedicated to migration concerns for lesbians, gay men, and binational couples - are not capable of or prepared for these challenges, I do want to suggest that religious institutions may be particularly well equipped to address some migration issues for same-sex binational couples in the contemporary political climate. In the context of the embattled discussion over faith-based initiatives and their increased role in providing support to marginalized populations in the United States, this consideration of the overlaps between human rights, MCC, and queer migration seeks to open new areas of dialogue surrounding these dynamics.

I framed this analysis ethnographically through an extended interview with a binational couple, Wuen-lin and [End Page 89] Michael. ${ }^{5}$ However, this research is not an empirical study

\footnotetext{
${ }^{4}$ Formerly, functions related to (im)migration were carried out by the Immigration and Naturalization Service (INS). Under the aegis of Homeland Security, the procedures formerly undertaken by the INS are now the responsibility of Immigration and Customs Enforcement, U.S. Citizenship and Immigration Services, and U.S. Customs and Border Protection.

${ }^{5}$ Wuen-lin and Michael's narrative history is simply one example of many potential intersections between sexual migration and the racial, ethnic, class, and geographic origins that invariably affect the dynamics of binational same-sex couple migration. As men from relatively economically privileged origins (in the global scheme of things), their experience cannot be taken as a representative case study. However, Wuen-lin and Michael's case does illustrate several of the central themes of the Metropolitan Community Church, human rights, and the
} 
of migration for lesbians, gay men, or partners in same-sex couples, nor is it a study centered on MCC's results or pragmatic accomplishments in facilitating such migration. My purpose here, in other words, is not to examine whether MCC's philosophical foundations work for same-sexattracted migrants but rather to explore how those foundations might be poised to do so. As such, this article is an exploration of the theoretical dimensions of queer migration, human rights, and the role of spiritual communities: an attempt to link the complexities of material, legal, political, ideological, and personal challenges of migration for partners in same-sex binational couples. I argue that approaching queer migration through a human rights framework offers a critical lens because it draws on transnational moral and humanitarian norms rather than depends solely upon the benevolence of sovereign states to liberalize their immigration policies. Through the lens of human rights, humanitarian ethics may be placed at the center; this move may be especially important to lesbian and gay people globally because homosexual relationships are illegal in approximately half the world's countries. Indeed, as Nancy Wilson (1995), the top-ranking official of MCC, put it, "In many places in the world, it is our humanness as gays and lesbians that is still the issue" (p. 16).

Binational same-sex couples, as well as individual lesbian and gay migrants, ${ }^{6}$ may especially benefit from the support of organizations, both religious and secular, for two key reasons. First, legal migration to the United States has largely depended on norms centered on the nuclear family, with visa regulations privileging family networks and familial ties to the United States. Both historically and at present, U.S. citizens or legal permanent residents have not been able to sponsor their same-sex spouses in the way that partners in heterosexual couples have been able to take advantage of the relatively simple conjugal route to immigration and citizenship in the United States. Second, although lesbians, gay men, and same-sex couples may have family in the United States, they may not have familial support because of their sexuality. Lesbian and gay migrants potentially lack the kin networks, as well as the social and financial support associated with kin networks, in both their countries of origin and their countries of destination, that prove so critical to nonlesbian and nongay migrants (Hondagneu-Sotelo, 1994; Mahler, 1995; Menjívar, 2000; Perez, 2004). Because of these obstacles, lesbian and gay migrants especially may require support from community or religious organizations, or both, to negotiate the many legal requirements for, as well as the social aspects of, migration to the United States.

In the same way that I suggest using a human rights framework as a way to look beyond the nation-state vis-à-vis lesbian and gay migration, so, too, I believe that it is necessary to think beyond the family as the hegemonic criterion for migration. Instead, I want to highlight the frameworks - practical and conceptual — of community-based and spiritually based collectives as a way to imagine new possibilities surrounding migration for same-sex-attracted individuals.

The article begins with a brief exploration of the foundations of human rights as an ideological starting point for migration of lesbians, gay men, and partners in binational same-sex couples. Human rights, though they are certainly open to various critiques, do offer ways to think through the many hurdles involved in border crossing, sexuality, and citizenship. I next consider the dynamics of migration - from legal histories of discrimination in U.S. (im)migration law to more recent lesbian and gay asylum claims and the 2005 Uniting American Families Act

potential pitfalls of migration. Their story serves as a guidepost for the discussion - it is not meant to insinuate that binational same-sex couples' migration is an issue limited to gay men or citizens of the developed world.

${ }^{6}$ Throughout this article, the term migrant designates a person who has crossed a U.S. border to seek permanent or temporary residence, either with or without legal documentation. 
(UAFA; formerly known as the Permanent Partners Immigration Act) — that attempt to mitigate the exclusion of lesbian and gay people hoping to find sanctuary in the United States. Drawing from the concept of sexual migration - when migration decisions are at least partially based on one's sexuality-I will propose that collective approaches can provide the necessary networks, tools, and ideological resources for migration of lesbians, gay men, and partners in binational same-sex couples. In particular, I consider the conceptual frameworks of the United Fellowship of the Metropolitan Community Church (UFMCC) as a way of examining these complexities. Undoubtedly, other religious communities might serve a similar purpose, including, potentially, those that are not part of the Christian tradition, such as mosques, temples, and sanghas. However, as the largest spiritual organization of lesbian [End Page 90] and gay people in the world, MCC offers an important case study. ${ }^{7}$ MCC has promoted an ideological flexibility, maintained transnational aspirations, and oriented its mission toward social justice, all of which resonate with the needs of binational lesbian and gay couples. Although organized religions are often seen as inflexible, rule-bound institutions that cannot allow for rights-based advocacy, I will propose that MCC offers a different sort of model. With its socially legitimatized status as a church, MCC has built a set of philosophical foundations through which human rights for lesbian and gay migrants might be effectively addressed.

\section{Human Rights and Lesbian and Gay Migration: In Search of Essential Truths}

Human rights begin with recognizing and affirming each individual's identity and value as a human being. Wuen-lin described how MCC had supported him and his identity:

\footnotetext{
What they talk about [at MCC] is essential truths-what it is to be a human being who happens to be queer. Not that it necessarily has to be a big deal to us, but because the world makes it a big deal we have to recognize it for what it is and we also have to deal with that part of it. It is a church that lets you know you are loved, unconditionally, in a community when we have been rejected by our family or friends. ...This is a place where they said no, you are loved. Period.
}

Michael added, "What its role for me is to be that spiritual touchstone to which I can go each week and reconnect with the essential part of being human."

Following a long tradition in Western political philosophy from Aristotle on, human rights have provoked questions about what it means to be human and, ultimately, how one's rights as a human being, as such, are to be configured. Addressing a group of international lesbian and gay rights advocates, Judith Butler (2004) emphasized that the category human is, in fact, redefined through transnational sexuality rights: "In the context of lesbian and gay human rights... certain kinds of violences are impermissible, [and] certain lives are vulnerable and worthy of protection, [and] certain deaths are grievable and worthy of public recognition" (p. 32). When people begin to take account of sexuality as an important axis of their humanity —as

\footnotetext{
${ }^{7}$ A number of the political advocacy organizations aimed at lobbying for lesbian, gay, bisexual, and transgender rights, both in the United States and internationally, also have significant membership bases. The National Gay and Lesbian Task Force, in existence for more than 3 decades, has approximately 20,000 members in the United States, and the Human Rights Campaign, founded in 1980, has had approximately 600,000 U.S. members over the course of its tenure. Two prominent organizations working toward establishing lesbian and gay rights internationally are the International Gay and Lesbian Human Rights Commission and the International Lesbian and Gay Association, which forms a network of 400 member organizations (or affiliates) from 90 countries.
} 
one of many elements of humanness - and as the world community recognizes potential violations based on this element of humanity, the often-taken-for-granted framework of human rights is challenged. As sexual rights gain recognition around the world, how are approaches to sexuality and lesbian and gay identity rethought or reordered in the international domain? In discourses of rights, how does one place sexuality at the center, not as an all-determining bedrock or essential attribute, but rather as one element that piques the question of how the category of human is subject to "redefinition and renegotiation" (Butler, p. 33). Since the broad outline of the protection of human rights has been put forth, ${ }^{8}$ many advocates - those fighting to end, for example, torture or female genital surgeries - have sought to expand the definition of human rights to encompass critical sites of struggle. Scholars have also sought to understand a more stubborn question, one that has existed since the classical age: What does it mean to be human? This question, in turn, leads to another: What is the nature of the rights that are attached to this humanity?

Michael Ignatieff (2001) claimed that the world was embroiled in the rights revolution, ${ }^{9}$ one that has been made possible, and necessary, in the wake of the declining [End Page 91] power of nation-states and the increased interconnectedness that leads to cross-national moral responsibilities - including a burgeoning "interest in the plight of immigrants and refugees worldwide" (Espín, 1999, p. 18). In practice, human rights concerns have recently proliferated in large-scale campaigns around the world. The creation of what have been called new rightswomen's human rights, children's human rights, indigenous people's rights, lesbian and gay and sexual rights, the right to development, and so on-has occurred in response to human suffering, dispossession, and displacement. The application of new rights in international documents, advocacy campaigns, and nongovernmental institutions has initiated a renaissance surrounding how human rights are to be defined and understood in their most expansive sense without losing sight of how to implement and achieve rights for very specific potential violations. Sexual migration and the legal status of lesbian and gay migrants and same-sex couples suggest several quandaries not only for the pragmatics of immigration law but also for human rights and notions of citizenship.

\footnotetext{
${ }^{8}$ The 1948 Universal Declaration of Human Rights (UDHR), developed largely in response to the Nazi Holocaust, maintained that citizens must be protected from potential abuses exercised by nation-states; to this end, the UDHR has sought to codify international norms of equality, moral standards, and humanitarian principles. The UDHR has also drawn attention to the facets of human life that had, historically, been used by states to deny people's rights. These included "race, colour, sex, language, religion, political or other opinion, national or social origin, property, birth or other status" (Universal Declaration of Human Rights, Document A 1810 at 71, article 2, ๆ 1).

${ }^{9}$ For a trenchant critique of Ignatieff's celebratory position on human rights, see Wendy Brown (2004). Although many would support the egalitarian aims of human rights in practice, there are also a number of well-founded critiques regarding the theoretical foundations of human rights and their current implementation. In brief, human rights, as I point out here, are overly reliant on nation-states and military intervention for their implementation (Agamben, 1998; Chomsky, cited in Feher, 2000); they are often part of neocolonial regimes, ensuring complicity with a putative civilizing mission that has its roots in European colonial hegemony. Formulations of which rights in particular (such as choice) are most worthy of protecting are also historically and culturally contingent entities (žižek, 2005). In this article, though I emphasize the usefulness of human rights as a political framework, I am also aware that rights are historically contingent, and in their application may erase cultural particularities in the service of universal rights (see Nagengast \& Turner, 1997).
} 


\section{Perplexities and Paradoxes: Lesbian and Gay Rights Beyond Legalism}

In The Origins of Totalitarianism (1958), Hannah Arendt posed a profound paradox between the role of governments (or nation-states) and their ability to protect the rights of their citizenry. According to Arendt, the case of refugees - stateless populations that had been deprived of civil and civic rights by virtue of their displacement - presented a breakdown and a fundamental challenge to the principles of human rights: Refugees, left with nothing but the "minimum fact of their human origin" (Arendt, p. 300), should have provided a quintessential embodiment of a pure subject for human rights. Instead, they invited a crisis of meaning. As she put it, "The world found nothing sacred in the abstract nakedness of being human" (p. 299). In the oscillation between the universal nature of human rights and their intended universal applicability, Arendt found that when a human is deprived of her or his sociopolitical identity, she or he ceases to be recognized as human. ${ }^{10}$

Similar to the refugee paradox Arendt (1958) described, undocumented migrants cannot claim full citizenship rights in the country to which they migrate because they are effectively betwixt and between, in a liminal condition of nation-state membership. Lesbian and gay people wishing to migrate, individually or coupled, also mirror the concerns that Arendt noted in the crises of the mid-twentieth century. Neither undocumented migrants nor lesbian and gay migrants can easily achieve full citizenship. Regular migration channels, for undocumented migrants, are largely foreclosed due to migrants' illegal status. In the case of lesbian and gay couples and individuals, they are additionally barred by their inability to legally marry a U.S. national and establish citizenship through a marital family tie. ${ }^{11}$ Many scholars of lesbian and gay and queer politics have argued that homosexuals have constituted a social class that has been legally defined, if incorrectly so, as deviant, criminal, or unworthy of equal legal protections and rights (Phelan, 2001; Stychin, 1994). This second-class citizenship, as Hull (2003) called it, thus has become one defining element of gay and lesbian identity — one that challenges human rights to achieve their original proposal to protect "without distinction" (p. 630). Despite the limitations of universalizing tendencies and legalistic limits, the humanitarian norms of human rights, with a jurisdiction that exceeds the nation-state, are well suited to operate as a set of principles to support lesbian and gay immigration rights.

Legalistic approaches to social change, as both part of and distinct from social or cultural transformation, have their place and their limit. Regular immigration is managed by the federal government and, as a brief review of U.S. immigration law will show, has often sought to control sexuality - usually under the mantle of racial, class, national, and moral considerations, as well

\footnotetext{
${ }^{10}$ It is not that human rights are prior to the political rights guaranteed by the nation-state, but the other way around. This situation creates a perplexity because human rights are essentially entrusted to states, which are also, ironically, the primary violators of human rights. This situation also creates "contradictions, [for] if they are supposed to be inalienable and universal, free from the determinations of any particular nation or state, [human rights] are also dependent on the sovereignty of that nation or state for their definition, protection and realization" (Balfour \& Cadava, 2004, p. 281).

${ }^{11}$ Of course, lesbian, gay, bisexual, and transgender (LGBT) people are allowed to marry an individual of the opposite sex in the United States and establish citizenship through a conjugal tie. Indeed, many do. However, this method has its price. In the first place, such a marriage is arguably illegitimate because it is based not on sexual affections and romantic commitments but on the desire to migrate; were such a marriage found to be a fraud, it would be grounds for deportation. Second, many LGBT people would argue that marrying someone simply to match a heterosexual paradigm and overcome legal immigration restrictions would be a betrayal of themselves and their sexuality.
} 
as fears. Legal mechanisms and approaches, as well as an ability to think outside of legalism (Halley \& Brown, 1999), need to be combined to effect lasting social change. Although nonprofit, nongovernmental, or religious organizations may be more precarious partly because their funding may be [End Page 92] less secure than that of governments, this positioning may also give them more authority than legislation alone. Religious institutions in particular, given their general social legitimacy and credibility, may offer holistic approaches to questions surrounding migration for lesbian and gay individuals and binational same-sex couples. The challenge is to incorporate the values of human rights without relying solely on legalistic, statebased approaches to social change.

\section{Migration: Surveillance, Sexuality, and Stories of Sanctuary}

During the Christmas season following September 11, 2001, Wuen-lin received a notice that he would no longer have a sponsor for his work visa: He would have to find another job willing to sponsor him, or leave the country. Wuen-lin described, "It's difficult...because you get comfortable and then have to change." Michael added:

\footnotetext{
[First], it was trying to get Wuen-lin here, then [because he had to be enrolled in a university in order to remain in the United States] it was school—papers and exams. You are afraid to settle in. I don't even want to get a pet, other than my 17-year-old cat, because you don't know what is going to happen. It's just too frightening to allow yourself to settle in.

Wuen-lin elaborated:

We are not very interested in a domestic partnership [which is available in the city in which they reside] because it is still a legal tracking...As free and open as we are here in San Francisco, in a lot of ways it feels like we are in the closet a lot.
}

Wuen-lin and Michael are relatively out about their homosexuality in the United States, but they are closeted in regard to Wuen-lin's immigration status. U.S. immigration proceedings are sites where sexuality - as well as race, class, and gender - are placed under surveillance, monitoring, and control. As regulatory statuses, citizenship and immigration are inextricable from the priorities of the nation-state and they convey implicit value systems affecting those who are allowed or disallowed entry. As Lauren Berlant (1997) put it, "Immigration discourse is a central technology for the reproduction of patriotic nationalism" (p. 195). The 2006 congressional legislation aiming to criminalize assistance to undocumented immigrants, and the massive protests that followed, are recent examples of both the regulatory system of immigration and its implicit values.

Geopolitical concerns and notions of national sovereignty intersect in immigration law. For queer migrants, argued Tomás Almaguer (1993), there are always potential barriers of racial, linguistic, or heteronormative discrimination in the United States. For example, the Mariel boatlifts from Cuba during the 1980s provoked fear in the United States that criminals and homosexuals were invading the country. Particular kinds of Cubans were considered less desirable and perhaps less morally upstanding than those who migrated for anticommunist, political reasons. Ironically, as Lourdes Argüelles and B. Ruby Rich (1985) argued, earlier queer Cuban migrants were used to paint an anti-Castro campaign that overemphasized the persecution of homosexuals in Cuba and was cited to legitimate U.S. policies. In these earlier waves of migration, the fact that homosexuals were being persecuted in Cuba and that some had been granted entry to the United States was used to bolster the image of the United States as being 
both modern and liberal. The U.S. government, however, continued to maintain several immigration provisions that barred homosexuals' entry to the United States thereafter. More recently, prohibitions against HIV-positive individuals can be seen as more in a long line of legal provisions that have drawn on fears of sexuality, concepts of disease, and issues of safeguarding the nation to impose immigration restrictions. Discourses on immigration also outline the prevailing conceptual borders of gender, sexuality, race, and class as they articulate with notions of the nation.

Martin Manalansan (1997) wrote that queers migrate not only as sexual subjects but also as citizens of nation-states that have a racialized, classed, and geopolitical history with the United States. Furthermore, migration is also conditioned by structural, historical, and military linkages between the United States and other nation-states that often provide bridges for migration (Sassen, 1996). The collapse of social support networks and the weakening of welfare states, in both sending and receiving countries, have created a world of relative transience and increases in migration globally. Although neoclassical approaches to the study of migration have emphasized a rational actor model - centering analysis on an individual who chooses migration based on very pragmatic, cost-benefit calculations - more recent scholarship (Fernández-Kelly, 1983; González-López, 2003; Grasmuck \& Pessar, 1991; Hondagneu-Sotelo, 1994; Pedraza, 1991; Portes \& Rumbaut, 1996; Sweetman, 1998) has explored the significance of race, gender, and class dynamics within migration. Although sexuality is certainly intertwined with the gender, racial, and class elements of one's identity - and, consequently, with immigration processesrace, class, and gender perspectives cannot substitute for the explicitly sexual or sexual identity dimensions of migration (Espín, 1999; González-López, 2005). [End Page 93]

Sexual migration (Cantú, 1999; Carrillo, 2004; Parker, 1997) provides a critique of purely economic (push and pull) interpretations of migratory motives. As an analytic framework, sexual migration attends to the role of social support networks that may not be kin based. Building on research specifically focused on gender and migration (Grasmuck \& Pessar, 1991; Hondagneu-Sotelo, 1994; Sweetman, 1998), the term sexual migration suggests a way to think through sexual desire and life goals related to one's sexuality and attends to the complexitiesphysical, psychological, and cultural - that arise when sexuality is taken into account. Sexual migration occurs when a person's decision to migrate is motivated by the hope of maintaining or establishing an affective, sexual, and committed relationship with a foreign national (Brennan, 2004; Cabezas, 1999; Cantú, 2002), or it may be linked to an individual's desire to explore her or his sexuality and sexual identity.

Sexual migration may also result from people making a move necessary for avoiding persecution or prosecution in their home country based on sexual behavior or status: For example, homosexuality is illegal in 85 countries and is punishable by death in eight countries, and other countries impose extended prison terms for homosexual behavior, actual or perceived (Ungar, 2001). Sexual migration may involve a search for more hospitable environs and a higher degree of tolerance for individual differences in sexuality and its expression. In the case of binational same-sex relationships, any and all of these elements of sexual migration may be at work. Here I focus on queer migration to the United States and the concerns related to this process. ${ }^{12}$ U.S. immigration law, as I will show, has maintained prohibitions related to sexuality

\footnotetext{
12 This process is limited, of course, because it cannot account for the particularities of migrants' countries of origin, nor can it fully consider the lives of people in same-sex affective relationships around the world more generally (e.g., Blackwood \& Wieringa, 1999; Boellstorff \& Leap, 2004; Carrillo, 2002; Gevisser \& Cameron, 1995; Howe, 2002, in press; Manalansan,
} 
throughout its history; however, the specific U.S. case I cite additionally demonstrates the importance of internal migration within the United States for lesbian and gay communitybuilding.

\section{Historicizing Lesbian and Gay Migration}

Migration, as such, is not all that new to lesbian- and gay-identified people in the United States; in fact, migration at least partially defines gay and lesbian identities in the United States. What Kath Weston (1998) called the Great Gay Migrations (p. 32) following World War II were made possible by increased employment opportunities in U.S. cities; the development of enclave communities, also called gay ghettos (Bérube, 1990; Chauncey, 1995; Kennedy \& Davis, 1994); and the linked processes of capitalist growth and gay identity (D'Emilio, 1983). The internal migration of lesbian and gay people to urban centers within the United States has, in many ways, defined the contours of many lesbian and gay communities. The contributions of foreign-born migrants to the construction of lesbian and gay communities and culture in the United States, however, have not been well documented (Román, 2000). With increased flows of people and capital in today's world, the shifting borders of lesbian and gay identities, politics, and communities need to be considered in an international framework.

The migratory barriers faced by same-sex-attracted individuals and same-sex couples cannot be understood outside the context of historical exclusions around perceived differences, including those of race, national origins, gender, and class. ${ }^{13}$ The explicit exclusion of lesbian and gay migrants to the United States began in 1917. At that time, the legal category "constitutional psychopathic inferiors" included "persons with abnormal sexual instincts" as well as "vagrants" and "pathological liars" (Loue, 1990, p. 126, n. 11), ${ }^{14}$ all of whom were prohibited entry to the United States. In 1952, legislation with two provisions to exclude homosexuals was instituted, barring immigrants who had committed "crimes of moral turpitude" (Canaday, 2003, p. 353), a designation based on behavior. It also barred the entry of homosexuals qua persons, a term used [End Page 94] to designate a category of person who was "afflicted with psychopathic personality" (Canaday, p. 353). The term psychopathic personality was sufficiently broad to envelop a number of conditions, including homosexuality as it was defined by the diagnostic norms of the time. In 1965, U.S. immigration law was again reworded and revised to exclude gays and lesbians under the aegis of their being "sexual deviates" (Luibhéid \& Cantú, 2005, p.

2003; Ratti, 1993; Rofel, 1999; Sinnott, 2004).

${ }^{13}$ The migratory barriers faced by same-sex-attracted individuals and same-sex couples cannot be understood outside the context of historical exclusions around perceived differences, including those of race, national origin, gender, and class. In 1790, U.S. law mandated that naturalization was reserved for Whites only. In the late nineteenth century, the Page Law (1875) prohibited Asian women from entering the United States because they were thought to be migrating for putatively lewd reasons. Chinese women in particular were singled out for immigration exclusion because they were marked as likely prostitutes. The Page Law was a harbinger of a yet more expansive Chinese Exclusion Act (1882) and the barring of southern European immigrants in the 1920s for similarly racialized reasons. Immigration law in the early twentieth century included prohibitions against women entering the United States for prostitution and forbade entry of so-called immoral women and polygamists (Hutchinson, 1981). Only in 1952 were all formal, explicit racial barriers removed from U.S. citizenship law.

${ }^{14}$ According to a 1918 Public Health Service manual for alien examination, "the moral imbeciles, the pathological swindlers, the defective delinquents, many of the vagrants and cranks, and persons with abnormal sexual instincts" (Public Health Service, 1918, p. 45; cited in Canaday, 2003, p. 359) were to be excluded. 
xiii). It was not until 1990 that a ban prohibiting entry of lesbian and gay immigrants was repealed.

The limitations of immigration law not only restrict individuals as such but also maintain larger conceptual frameworks: in particular, a focus on the family. Shane Phelan (2001) argued that an increasing heterosexualization of U.S. citizenship has occurred throughout the twentieth century. In 1965, revisions to immigration law demonstrated a renascent commitment to the heterosexual nuclear family by mandating that $75 \%$ of permanent visas would be granted only to those with family ties in the United States. These family provisions - with preferences given to spouses, children under 21, and parents of adult U.S. citizens-also affected the ability of Asians and Africans to migrate to the United States. Because migrants from Asia and Africa had been barred for so long historically, many potential migrants were consequently without the quotient of family ties required by the 1965 codes (Reimers, 1992).

Drawing from discourses of protecting the public health of the body politic, in 1987 HIV/AIDS was added to the list of contagious diseases for which immigrants could be excluded entry. Congressional legislation in 1993 amended the Immigration and Nationality Act (1952) to bar "HIV-positive aliens applying for immigrant visas, refugee visas, and adjustment to permanent resident status" (Barta, 1998, p. 336). ${ }^{15}$ In 1996, the Immigration and Naturalization Service stated that HIV-positive status could be grounds for seeking asylum, allowing discretionary relief to HIV-positive individuals. Although lesbians and gay men comprise only a small percentage of the world's HIV-positive people, this prohibition, as well as the partial remedy through asylum, has affected some queer individuals' ability to migrate.

Although the United States has allowed openly identified lesbians and gay men to enter only since 1990, the United States continues to figure as a sanctuary for many-particularly those who come from home countries that may have repressive laws against homosexuality. Along with establishing more liberal laws regarding lesbian and gay migration and asylum seeking (McClure, Soloway, \& Nugent, 1997), the United States appears, to many around the world, to be a haven for sexual minorities and, by extension, for binational or dual-migrant samesex couples. According to Luibhéid and Cantú (2005), lesbian and gay migration narratives tend to be oriented around a movement "from repression to freedom" or a "heroic journey undertaken in search of liberation" (p. xxv). Although the realities of migration processes and lesbian and gay tolerance in the United States are more complicated than that, it is nevertheless important to recognize that the perception of relative freedom in the United States often provides motivation for same-sex couples' migration.

\section{Strategizing Sexual Migration: Advocacy Organizations and Legislative Interventions}

Despite many challenges, lesbian and gay migrants do enter the United States: some closeted, some out, some undocumented, and some under asylum (Ranck, 2002). Because of the inherent complexity of immigration law, advocacy organizations, information centers, and websites have been instrumental to the migration of lesbians, gay men, and same-sex couples to the United States. More recently, the same-sex marriage movement in the United States has

\footnotetext{
${ }^{15}$ From Section 212(a)(1)(A)(i) of the Immigration and Nationality Act (1952). Though legal details change, an HIV waiver is available to foreign nationals who have qualifying relatives in the United States and can demonstrate that they will cover the costs of any medical treatment associated with the disease. Asylees and refugees may apply for an HIV waiver even without a qualifying relative.
} 
sparked congressional legislation that would qualify same-sex couples for visa provisions similar to those of heterosexual couples. In addition to the multiple dimensions of pending law, organizations that educate and advocate on behalf of lesbian and gay migrants also offer perspectives on the concerns of lesbian and gay migrants.

The concerns of lesbian and gay migrants may include not only a fear of disclosing their sexual identity to immigration officials but also a fear of letting their families know about the reasons behind their migration. Responding to the question, "Are you out to your family?" Wuen-lin answered:

\begin{abstract}
Well, yes and no...my family still thinks I live with a roommate. My sisters know, but my parents don't know. They've been here to visit and they know who Michael is and they ask about him every time they call. But now they are asking when am I going back [to Singapore]. That is another challenge I have to face soon. I don't even know [how to say the word] homosexuality in my language to be able to tell my mother.
\end{abstract}

Many lesbian and gay individuals and binational same-sex couples are reluctant to reveal their sexual [End Page 95] identity to immigration officials for fear of deportation. Therefore, it is very difficult to know exactly how many binational same-sex partners currently live in the United States. Only a handful of organizations in the United States - including Immigration Equality, ${ }^{16}$ the Human Rights Campaign, ${ }^{17}$ and Loves Sees No Borders ${ }^{18}$ - address the concerns of binational same-sex couples, as well as issues of lesbian and gay migration more generally. Marta Donayre (2002), cofounder of Love Sees No Borders, claimed that approximately half a million members of same-sex binational couples in the United States had come from a range of social, economic, political, and national origins (p. 25). In the 2000 U.S. census, according to Immigration Equality (2005), 6\% of the 594,391 same-sex unmarried partners included one citizen and one noncitizen, making an estimated 35,663 same-sex binational couples in the United States. Furthermore, 27,546 same-sex unmarried partners reported in the 2000 census that both of them are noncitizens. Thus, a total of 63,209 same-sex unmarried couples in the United

\footnotetext{
${ }^{16}$ Immigration Equality (formerly the Lesbian and Gay Immigration Rights Task Force), the only such national organization in the United States, has 19 chapters across the country and provides outreach, advocacy, and education about lesbian and gay and HIV-positive migration to the United States. As a grassroots organization, Immigration Equality aims to establish legal equality for lesbian and gay and HIV-positive individuals under U.S. immigration law. Founded in 1994, with national headquarters in New York City, it has grown to a membership of 10,000 . It is funded by private foundations such as the Ford Foundation, George Soros's Open Society, and the lesbian and gay foundation Horizons, among others, as well as by members' donations.

${ }^{17}$ The Human Rights Campaign (HRC), a large, well-known, national lesbian and gay rights organization that has been a strong supporter of marriage equality (or same-sex marriage), also supports the cause of binational samesex couple migration. Though migration is not one of their central issues, the HRC website directs visitors to the Immigration Equality website; one such link has the prompt, "If your partner is about to be deported." HRC also features information about the Uniting American Families Act. HRC's approach to the question of lesbian and gay or same-sex couple migration follows in step with the organization's more general orientation to normalize (Warner, 1999) homosexuality and gay and lesbian relationships within larger social frameworks through the models of family and long-term monogamous partnering.

${ }^{18}$ Love Sees No Borders is a much smaller organization focusing solely on binational same-sex couple migration. The organization defined itself as "dedicated to disseminating information about the injustices suffered by gay Americans and their foreign-born partners" (Love Sees No Borders, 2005, ๆ 1). More recently, the organization has defined itself as advocating "on behalf of binational same-sex couples in trying to live in the Unites [sic] States" $(2007$, १ 1). Love Sees No Borders does not consider itself a political or advocacy organization per se but rather an educational resource for binational same-sex couples.
} 
States include one or both partners who are noncitizens. In other words, of the overall 594,391 total couples who reported as same-sex unmarried partners in the 2000 census, more than $10 \%$ of them had at least one noncitizen. Because U.S. immigration law recognizes only heterosexual married couples, these same-sex partners cannot file visa applications or register citizenship claims based on their committed relationships. Therefore, same-sex couples may continually face a threat of one or both partners being removed from the United States for a number of different reasons, such as an expired tourist, student, or work visa or lack of initial immigration documentation.

\section{Legislation and Legitimacy of Same-Sex Partnerships in U.S. Immigration Law}

Seventeen countries (Australia, Belgium, Brazil, Canada, Denmark, Finland, France, Germany, Iceland, Israel, the Netherlands, New Zealand, Norway, South Africa, Spain, Sweden, and the United Kingdom) currently recognize same-sex couples for immigration purposes, ${ }^{19}$ with Belgium, Canada, the Netherlands, and Spain granting the right for same-sex marriages as well. The situation is quite different in the United States.

Most frequently, immigrants to the United States become legal permanent residents through employer sponsorship or direct family ties. Although heterosexual couples can marry and thereby create a direct family tie through a conjugal relationship, the same possibility does not exist for same-sex binational couples. The so-called culture wars in the United States continue to rage over the question of same-sex marriage, from constitutional amendments aimed at prohibiting same-sex marriage to social activism aimed at ensuring same-sex [End Page 96] marriage equality. The Defense of Marriage Act (DOMA) legislation, enacted in 1996, continues to prohibit same-sex binational marriage claims because, for immigration purposes, the DOMA legislation defines marriage as a relationship between a man and a woman. At the federal level, the United States neither recognizes the legal legitimacy of same-sex marriage nor allows naturalization claims to be made on the basis of direct family ties through same-sex partnerships. Any state-based rights granted to same-sex couples (such as civil unions or domestic partnerships in California, Hawaii, New Jersey, and Vermont, and marriage in Massachusetts) are ineligible for immigration claims because immigration and citizenship considerations operate at the federal level (through the Department of Homeland Security) and therefore are unaccountable to individual states' definitions of immigration-viable partnerships. However, legislation intended to transform the federal immigration status of same-sex couples has recently been placed before Congress.

\footnotetext{
${ }^{19}$ In 2003, Brazil's National Immigration Council instituted Administrative Resolution No. 3, which recognized legal same-sex unions performed abroad for immigration purposes (Immigration Equality, 2004). Following an earlier finding in favor of a binational (British and Brazilian) gay male couple residing in Brazil, the resolution effectively "disposes of the criteria for the concession of temporary or permanent visa, or of definitive permanence to the male or female partner, without distinction of sex (Diário Oficial da União, cited in Immigration Equality, ๆ 2). Same-sex couples who have been legally married (in Belgium, the Netherlands, or Canada), or are in a civil union or domestic partnership (in Vermont or California, for example), or registered as partners in a city registry (in San Francisco or Buenos Aires, for example) can use their certificate to apply for immigration benefits in Brazilmaking it the first country in Latin America to extend such an opportunity.
} 
Introduced in 2005 as an amendment to the Immigration and Nationality Act, ${ }^{20}$ the UAFA would allow U.S. citizens and legal permanent residents to sponsor their same-sex partners for immigration purposes. Essentially, the amendment adds the terminology permanent partnership after the term marriage to the Immigration and Nationality Act. The UAFA outlines detailed parameters intended to ensure that only committed same-sex partners are able to use it. Although the wording of the bill does not explicitly mention same-sex partners, it does specify that the couple must be "unable to contract... a marriage [with said partner]" (Uniting American Families Act [UAFA], 2005, § 101[a], C). In other words, one cannot immigrate as an oppositesex unmarried couple, but same-sex partnerships have a unique provision. Resistance to the amendment has included the claim that to legally facilitate same-sex spousal sponsorship would be tantamount to allowing a tide of alleged partners and immigration fraud. Like heterosexual married couples, same-sex partners would need to show financial interdependence as proof of their committed relationship. Violation of the UAFA by fraudulent same-sex partnerships would incur steep fines, just as does fraud for heterosexual marriages that are illegitimately contracted solely for immigration purposes. Passage of the UAFA would constitute an important leap forward for the cause of binational lesbian and gay couples, moving the United States closer to the norms of similar nation-states, such as the 17 countries listed previously that currently recognize same-sex couples for immigration purposes.

The UAFA does continue to rely on the trope of the family, centered as it is on the concept of a couple with a "lifelong commitment" (UAFA, 2005, § 2, II 1), with permanent partnerships serving a symbolic and legal role similar to that of the traditional married couple (Lewin, 1998). The UAFA does not, however, make the more profound move of examining the universality of the nuclear family form or, as Doreen Indra (1999) put it, "the notion of 'the'

\footnotetext{
${ }^{20}$ The Uniting American Families Act (UAFA) was submitted to the 109th Congress as S. 1278 and H.R. 3006, formerly called the Permanent Partners Immigration Act (S. 1510 and H.R. 832). In 2005, the UAFA was introduced by Representative Jerrold Nadler (D-NY) and Senator Patrick Leahy (D-VT), though it was not enacted. The wording from Section 2, "Definitions," is as follows. ๆ 1:
}

Section 101(a) (8 U.S.C. 1101(a)) is amended-

(1) in paragraph (15)(K)(ii), by inserting "or permanent partnership" after "marriage"; and

(2) by adding at the end the following:

The term "permanent partner" means an individual 18 years of age or older who-

(A) is in a committed, intimate relationship with another individual 18 years of age or older in which both parties intend a lifelong commitment;

(B) is financially interdependent with the individual described in subparagraph (A);

(C) is not married to or in a permanent partnership with anyone other than the individual described in subparagraph (A);

(D) is unable to contract, with the individual described in subparagraph (A), a marriage cognizable under this Act; and

(E) is not a first-, second-, or third-degree blood relation of the individual described in subparagraph (A). 
household itself' (p. 14). If it were to be made law, the UAFA would constitute an important victory for lesbian and gay immigration equality but it would not unseat the ideological ideal of the nuclear family that lies at the heart of U.S. immigration law.

Under immigration law, entry into the United States is framed as a privilege - one that may be summarily denied. However, asylum and refugee conventions follow different epistemologies and are linked to broader frameworks, including U.S. foreign policies and international human rights conventions. The refugee and asylum system came into being globally following World War II, and the purpose of asylum is an explicitly moral one: attempting to provide people sanctuary from persecution based on race, religion, nationality, political opinion, or membership in a particular social group (following the [End Page 97] Universal Declaration of Human Rights, 1948). ${ }^{21}$ Although asylum seekers in the United States were initially conceived through a model that assumed a politically persecuted and autonomous male subject, there have been significant changes in recent years. Accounting for the legal category of a social group or a political opinion, particularly as such categories pertain to sexuality and gender, has become a key question in U.S. asylum law. Since the early 1990s, judicial proceedings have considered, in rather profound ways, persecution based on sexual orientation and gender identity; it is in this area that important new precedents have been set.

In 1994, former U.S. attorney general Janet Reno declared the Matter of Toboso-Alfonso to be precedent. In this case, a Cuban gay man was found to be eligible for withholding of removal (not deportable) from the United States because he was a member of a particular social group: homosexuals. Toboso-Alfonso established that a well-founded fear of persecution on the basis of one's sexual orientation is a valid basis for an asylum claim in the United States. Since the Toboso-Alfonso case, courts have generally been more likely to expand the definition of what constitutes a social group, including girls and women who have undergone female circumcision (genital surgery or genital mutilation) or are victims of domestic violence. Although there is no clear statutory definition of what counts as membership in a particular social group, the concept has been used generally to designate a group with immutable characteristics - shared qualities that members of the group cannot, or should not, be required to change. Since the Matter of Toboso-Alfonso, more than half a dozen precedents have been set regarding gay, lesbian, bisexual, transgender, and HIV-positive asylum cases (Immigration Equality, 2007).

Negotiating the complexities of the legal system and immigration law in the United States, particularly for those who may be undocumented migrants, can be an overwhelming experience, as well as a financial and logistical burden. Procuring transportation to the United States, recruiting attorneys, and paying legal fees and living expenses, in addition to spending the enormous amount of time needed to file documents and set up possible trial dates, as well as meet with lawyers, judges, and immigration and naturalization officials, can add up to an insurmountable task (Ranck, 2002). No matter which route a lesbian or gay migrant or binational couple may choose for legal migration, it is a highly class-dependent proposition. International student visas require the holder to demonstrate that she or he has sufficient funds for tuition (often higher than the rate charged to U.S. residents), and international students are prohibited from working in the United States. Work visas require that the holder have skills that the employer requires, and although the employer may have a stake in retaining the employee, the migrant is also more prone to the vicissitudes of employment. A person with significant financial resources may acquire an investor's green card or create an international corporation,

\footnotetext{
${ }^{21}$ The 1951 UN Convention on the Status of Refugees, as well as the later incorporation of the Refugee Act into U.S. law in 1980, created the legal structure and system of settlement to ensure the rights of asylum seekers.
} 
but these options are available to only an elite few. Migration is never free from the very concrete, material realities of adequate funding, time, and informational resources. In other words, the migration process requires a sufficient network of support, knowledge, and commitment.

\section{MCC: A Spiritual Philosophy for Lesbian and Gay Migrants?}

For Wuen-lin and Michael, the community they found through MCC and the Lesbian and Gay Immigration Rights Task Force ${ }^{22}$ was very important because it provided a support network. Wuen-lin explained:

Basically, it is our extended family. I feel they care for me and they listen to me and they worry about me. At the same time, I feel I have a role to play in that relationship. If they need me to do anything and I am able to do it, I'll do it. That is my community.

Michael added:

[Wuen-lin's] spirituality, his identification with Christianity, his faith is such an important and essential part of him...even though I wanted nothing to do with Christianity and all of that, I could not not be a part of such an important part of him. ...And so if I am going to go, then the compromise was that this was the church I would feel most comfortable going to because I have been working and living in the Castro [neighborhood in San Francisco] for a few years, enough to know their [MCC's] reputation for social justice and that they are the queer church, the gay church - they were the gay church when no other church would have us. [End Page 98]

Wuen-lin interjected:

Actually for me, the first day I walked in, it's like [looking around with elation], "Oh, wow...I'm home." I really feel very comfortable there. In Singapore, I attended church regularly but I didn't contribute to the church because I didn't see the money going anywhere; they didn't organize anything, not any social justice programs. To them, the money is used for church picnics, barbecues...I have never gone to any other church here [in the United States] but MCC.

MCC, as Michael put it above, was "the queer church, the gay church." MCC describes itself as ministering primarily within the lesbian and gay community, although it is open to all. MCC is also considered to be one of the largest grassroots organizations of LGBT people in the world, with 230 congregations in more than 20 countries. MCC is first and foremost a religious community, but social action has been part of its agenda from the beginning (Warner, 1995). The sheer size and scope of the UFMCC, its locations in numerous countries, and its longstanding commitment to lesbian and gay people and their rights suggest that as an institution, MCC might form an ideal nexus to address migration concerns for lesbians, gay men, and binational samesex couples from an advocacy point of view.

\footnotetext{
${ }^{22}$ As previously noted, the Lesbian and Gay Immigration Rights Task Force (LGIRTF) is now Immigration Equality. However, Wuen-lin and Michael referred to the organization as LGIRTF, so I have preserved that phrasing here.
} 


\section{Queer Community and Border-Crossing Liturgies}

The origin story of MCC is one of overcoming discrimination. The founder of MCC, Troy Perry, took the position that the Bible itself does not condemn homosexuality per se. Rather, he explained that "the six clobber passages" derogating homosexuality had been interpreted out of context (MCC message from Perry, April 18, 2002). Rather than reading these lines in context and accounting for changing historical conditions, Perry asserted, people had used these passages to discriminate against lesbian and gay people, who are themselves God's creation. It is upon this unjust paradox that Perry founded his church:

I know that intolerance is an enemy of mine just as it is an enemy of God's. I know that people are intolerant of those - the "theys" - of the world, and a part of my mission is to eliminate that attitude of "they." I have learned that man is alone everywhere, especially homosexuals. ... The religious feelings of these, my people, are very deep. (Perry, 1972, p. 5)

Perry's explicit framing of those he calls his people in a struggle against intolerance pointed to the nascent emergence of a larger, collective ethos - a form of lesbian and gay or queer kinship and relatedness that would develop over time in MCC.

MCC originated theologically from American Pentecostal roots ${ }^{23}$ and Perry's early spiritual training (Perry, 1972; Warner, 1995). Since then, the church has become a much more eclectic mix of liturgical forms that include Catholic, Episcopal, and Lutheran approaches (Dank, 1973) as well as, in some congregations, goddess worship, New Age spirituality, and universalism (Warner). MCC has also reworked its approach to favor inclusive language. For example, the Lord's Prayer may be spoken using the words our creator or our sustainer in lieu of our father (Warner), thus shifting from a patriarchal, family-based discourse to one that attempts to signal a move beyond the family.

The Reverend Elder Nancy Wilson (1995), a member of MCC since 1972 who succeeded Troy Perry as moderator of the UFMCC, formulated a sense of lesbian and gay or queer collective identity through the trope of the transnational tribe when she asked, "Who are gay men and lesbians? Sometimes, in my deepest self, I feel like we are some ancient tribal remnant that has survived and that now appears to be dispersed among every other earthly tribe-a transnational tribe!" (pp. 11-12). Wilson's invocation of a tribal collective sentiment and history is not new to gender and sexuality epistemologies. Indeed, creating a sense of historical legacy and legitimacy associated with tribal origins is a way in which marginalized people, whether gay or not, have historically sought to cement their sense of identity.

Similarly, feminist and postcolonial scholars have described strategic essentialism as a way to acknowledge the constructed nature of identity while putting to political use putatively innate differences to invert the oppressive tactics of colonial and positivist essentialism. Strategic

\footnotetext{
${ }^{23}$ R. Stephen Warner (1995) argued that the Metropolitan Community Church (MCC) has depended on what he called conservative foundations of Pentecostalism and essentialism in order to advance its rather progressive cause: a lesbian and gay church that challenges homophobia and provides a spiritual home for gays and lesbians in contrast to the hostility of many mainstream churches. Central to MCC's effectiveness, in his formulation, is the fact that it is an American church growing out of Pentecostal vitality and scriptural interpretation, which has allowed for liturgical flexibility. Warner described the history of MCC as one that has followed a conventional teleology of development, growing from a congregation to a denomination (the Universal Fellowship of Metropolitan Community Churches) and ultimately aspiring to become part of the National Council of Churches (also see Warner, 2005; Wilcox, 2003).
} 
essentialism can then serve as a powerful mechanism for social change, albeit one that is limited by its reliance on [End Page 99] innate and immutable differences. Lesbian and gay and queer scholarship, as well as queer communities, have shaped similar forms of association, whether through fictive kinships described as families they choose (Weston, 1991); a queer nation (Patton \& Sanchez-Eppler, 2000; Seidman, 1996); or a queer planet (Warner, 1993) — though these claims for community do not necessarily draw from essentialist claims. The kind of strategic essentialism that emerges out of a globalized, tribal conception of lesbian and gay people is also particularly well suited to human rights imperatives. Recall that the United Nations recognized that "membership [in] a particular social group" may lead to a refugee's inability, or unwillingness, "to return to [his or her country]" (United Nations General Assembly, 1951, II 1). These tenets have been a central discourse in precedent-setting asylum claims in recent years.

By imagining an innate quality of homosexuality, both Wilson and Perry suggest a form of queer kinship or a tribal ethos that potentially serves the larger social justice concerns of MCC and its members. Although scholarly critiques of essentialist sexuality have prevailed throughout the 1990s, particularly in queer theory, in practice some forms of strategic essentialism might be deployed to achieve reformist political goals. However, whether this ethos of tribal kinship works in practice for all the parishioners of MCC is debatable. Although the epistemological foundations may coincide in important ways with the advocacy goals of migration for people in binational same-sex couples, this sort of spiritual essentialism cannot be expected to work for all potential migrants, at least partially because a religious preference (in this case, Christianity) is involved. Moreover, although MCC may prescribe an essentialist orientation, many parishioners perhaps cannot, or choose not to, take up this particular mantle for myriad reasons.

The essentialist concepts illustrated in both Perry's and Wilson's reckonings of homosexuality and lesbian and gay solidarity provide a formula that might exceed the heteronuclear family models so entrenched in immigration law. And yet, MCC has rather famously been performing same-sex wedding ceremonies since the founding of the church in 1969. According to the MCC website, MCC ministers perform 6,000 weddings annually in their churches around the world (Metropolitan Community Churches, 2006). More recently, MCC has been a strong supporter of same-sex marriage equality. Although some would argue that samesex marriages are a recapitulation of heteronormative pair-bonding, by virtue of their same-sex gendering these ceremonies also need to be understood as a challenge to presumed heterosexuality. Beyond same-sex weddings, the larger ideological framework of MCC aims to create a sense of community, one that is to some degree essential and tribal (in Wilson's phrasing) - a kinship extending beyond the heteronuclear family form. Nevertheless, this longstanding commitment to same-sex marriages suggests that MCC may not diverge radically from a family-based model, limiting MCC's ability to argue against these entrenched biases in immigration law.

MCC's strategic essentialism and tribal kinship do have the potential to unsettle heterosexual kinship and family models that have so dominated migration law in the United States, though whether this potential would manifest in reality remains an open question. The conceptual frameworks of essentialism and tribal kinship, however, also dovetail well with some of the fundamental principles of human rights epistemologies. Seeming to speak to one of the central questions of human rights political philosophy — what constitutes the human - Wilson (1995) asked: 
So, do gay and lesbian people identify more with our tribe(s) or more with our humanness...Those in whatever dominant group or culture always want all the rest of us to focus on our generic humanness, on how alike we are, not on our differences. (p. 15)

\section{At the Heart of It: Social Justice and Human Rights}

"For Troy Perry," who founded MCC in 1969, "religion had always been a matter of love, not law" (Warner, 1995, p. 87). Although love may have come before law, seeking social justice, sometimes through legal channels, has also been central to MCC's work. MCC became an institution through one of the momentous political and cultural agendas of the day, the gay liberation movement in the late 1960s and early 1970s. Following a survey of gay rights movements in the early 1980s, Dennis Altman (1982) suggested that MCC was, in many places, singular in its ability to gather a committed gay constituency: "[I]n many places the church is the only form of the gay movement that exists" (p. 123). Having established itself as a key site committed to the gay movement, in $1978 \mathrm{MCC}$ went on to help defeat the Briggs Initiative in California, which sought to prohibit gay men and lesbians from being teachers (Perry \& Swicegood, 1990). More recently, MCC has called for federal legislation on hate crimes and lobbied for antidiscrimination laws to protect lesbian and gay people.

Although undertaking social justice projects runs through the history of MCC, a new emphasis on human rights, as such, pervades current MCC discourses and the ways that MCC frames its social justice work. UFMCC's Statement of Vision says, "Metropolitan Community [End Page 100] Churches are on a bold mission to transform hearts, lives, and history. ... Just as Jesus did, we are called to: Do justice, show kindness, and live humbly with God (Micah 6:8)" (Metropolitan Community Churches, n.d., II 1).

MCC social justice projects include achieving the Millennium Goals (the United Nations poverty-reduction campaign), working against the spread of HIV/AIDS and caring for HIVpositive individuals and their families, advocating for marriage equality, and creating online communities (e.g., Living Fusion, which aims to organize social action around the world). Thus, in addition to its inclusive approach to the liturgy and a form of essentially defined connectedness of lesbian and gay people, MCC continues to emphasize the centrality of social justice and human rights.

\section{San Francisco}

The Metropolitan Community Church of San Francisco (MCCSF), the second-oldest lesbian and gay congregation in the United States, was founded in 1970 by Reverend Howard Wells. In its online discussion about values, MCCSF noted, "We believe that all people are equally deserving of God's love and that all people share inalienable human rights" (Metropolitan Community Church of San Francisco [MCCSF], 1998-2006b, II 9). Following both the human rights framework and the eclectic approach of the larger UFMCC liturgical style, MCCSF goes on to describe that it is "influenced by liberation, inclusive, and feminist as well as traditional theologies... various Christian and non-Christian traditions" (MCCSF, 1998-2006a, II 2). The congregation strives for inclusive, non-gender-biased language and states a desire to extend church membership to all while providing "a home for queer spirituality" (MCCSF, 1998-2006b, II 7). 
With its church status, which helps define MCC as a sanctioned institution for good works, ${ }^{24}$ MCC may also evade some of the volatile politicization that is inherent in the hotly contested issues of both same-sex marriage and immigration. Many churches, mosques, and temples are committed to doing good works in their communities. However, in combination with the church's long-standing support of lesbian and gay people and human rights, MCC is philosophically well suited to meeting the challenges of binational lesbian and gay migration issues. Whether dealing with such concerns can be productively undertaken in practice and not simply in theory remains to be seen. MCC's approach to inclusiveness, which attempts to establish an expansive sense of us-ness without excluding non-lesbian and non-gay people from its ministry mission, may also prove politically advantageous. MCC makes claims of an overt inclusiveness rather than depending on exclusionary forms of identity politics that might be seen as divisive, perhaps especially by right-wing foes. Embedded in the MCC philosophy are the seeds of a larger transnational lesbian and gay ethos, one that is inclusive and, more important, explicitly global. According to MCCSF, "We build and grow a beloved community of queer people, family, and friends that is local and global, physical and virtual" (1998-2006b, II 14).

The global scope of MCC is critical in an era of pervasive migration and increased interconnectedness; of course, many of the so-called world religions have global scope. The question is how well MCC or other faith-based communities and institutions will be able to rally their globality and commitment to social justice in support of concerns surrounding migration issues for lesbian and gay individuals and binational same-sex couples. MCC's focus on lesbian and gay members is a central element suggesting that the MCC could become a logical location through which to address migration issues for lesbian and gay people. MCC was conceived out of both spiritual and political commitments, particularly through some of the early work of founder Troy Perry. His proposal, situated within a varied liturgical style, was that homosexuality is innate (or essential) ${ }^{25}$ and that as such, it is a gift from God (Warner, 1995). Using the trope of essentialism and a linked sense of community through the tribe, MCC mirrors many of the political strategies that have proven [End Page 101] effective in ethnic, gender, and other sexuality-based struggles for human and civil rights. As the comments of Wuen-lin and Michael made clear, these strategies are more than just political and rhetorical: They are, for many MCC parishioners, deeply felt. Although many MCC members may benefit from and embrace these narratives of kinship, community, and tribal membership, it is not clear whether such tropes work effectively for all of those involved. That is, essentialism has its limits, as the past 2 decades of identity politics have demonstrated; MCC's inclusiveness may work well as a

\footnotetext{
${ }^{24}$ Through outreach and voluntarism, the Metropolitan Community Church of San Francisco (MCCSF) seeks to transform the larger social world. The congregation has a shower project aimed primarily at San Francisco's homeless population, a meal program, cancer support groups, and a program to provide foster children with suitcases so they need not use garbage bags to move from one home to another. The congregation has worked with the San Francisco Department of Public Health to provide HIV testing on location in the church building. MCCSF also created the Harvey Milk Civil Rights Academy, named for the gay member of the San Francisco Board of Supervisors who was murdered in 1978.

${ }^{25}$ See, for example, Dennis Altman's Homosexual: Oppression and Liberation (1973) for an ideological overview of the gay liberationist struggle that aimed, not unlike a later iteration in queer movements in the United States, to point to the bisexual and latent homosexual potential in everyone rather than centering dialogue on an exclusive homosexuality among a minority population. Using Herbert Marcuse's Eros and Civilization: A Philosophical Inquiry Into Freud (1966) and Alfred Kinsey and his colleagues' survey work (1948, 1953), gay liberation (in broad strokes) underscored both the centrality of sexuality as a social site of repression (following Marcuse) and the continuum of homoerotic experience (following Kinsey).
} 
theoretically rich avenue for lesbian and gay migration, but the proof of its utility in practice remains to be seen.

Beyond its transnational commitment to lesbian and gay issues, since its inception MCC has had at its core four key components that appear, theoretically at least, to situate MCC as a social and spiritual location that might be particularly suited to the cause of migration issues for lesbians, gay men, and same-sex binational couples. First, drawing on discourses of a tribal community or kinship among and between lesbian- and gay-identified people around the world, MCC advocates for an expanded sense of relatedness. This sensibility, a larger ethos of queer people, is an ideological position that is poised to reach beyond the parameters of the nuclear, heterosexual family that has been so foundational to the last decades of immigration legislation in the United States. Second, MCC has also held, since its beginnings in the late 1960s, that social justice and, more recently, human rights are central to its mission, vision, and practice. Third, MCC can draw on its putatively apolitical identity as a church, with the legitimating power of churchness, in ways that nonprofit, nongovernmental organizations and groups may not be able to. Although MCC may not have the explicit approval afforded to some other religious institutions (arguably because it is a so-called queer church), it does nonetheless occupy "the legitimate social space accorded to religion in the United States" (Warner, 1995, p. 82), which may shelter the institution from some political attacks. Although religion in the United States can hardly be said to be an apolitical arena, the marriage of Christianity and good work-the stuff of most churches, including MCC - may ameliorate some of the political vitriol so infamous in debates about homosexuality and migration. Finally, MCC has been a geographically particular church, one that has evolved out of and continues to thrive in urban spaces with a relative tolerance for gays and lesbians. That is, it is a church that was largely born through the Great Gay Migrations (Weston, 1998). MCC was founded in Los Angeles, California (where the primary MCC remains), but MCCs have developed other thriving congregations in the United States, many in migration gateway cities in the southwestern and southern United States.

The way that MCC has combined an expanded sense of kinship and family (Weston, 1991) with essentialist renderings of homosexuality, commitments to human rights, church legitimacy, and migratory origins suggests that MCC is well positioned with respect to the issues surrounding the migration of lesbians, gay men, and partners in binational same-sex couples to the United States. MCCSF, which has served as a brief case study here, presents one example of MCC's values and practices in an important gateway city for both international migrants specifically and lesbian and gay people in general. In a recent sermon at MCCSF, then-Reverend Dr. G. Penny Nixon underscored the nexus of migration and sexuality when she described Jesus as a border crosser (Nixon, 2006). Nixon's emphasis was on Jesus's ability to transcend the strictures of religious and ethnic boundaries and extend compassion to all. Given that her sermon occurred during the height of the 2006 immigration rights protests, there is an uncanny resonance between MCC's message and the turbulent politics of immigration in the twenty-first century.

\section{Conclusions}

The relationship between U.S. (im)migration and LGBT lives demonstrates both possibilities and prohibitions. For many years, lesbian and gay people were explicitly barred from obtaining the right to immigrate to the United States. Yet, many lesbian- and gay-identified people around the world have held out hopes for sanctuary in the United States. In a 
contemporary context, questions concerning the migration of lesbians, gay men, and partners in binational same-sex couples offer a particular opportunity to revisit the crisis of meaning that has troubled political theorists and human rights advocates alike regarding how human rights, supposedly the most fundamental rights owed to everyone, are distributed - either through state bureaucracies or in the domain of international moral injunctions. As with earlier refugee paradoxes, undocumented migrants and lesbian and gay people each face difficulties in claiming full citizenship, either by virtue of their undocumented status or by virtue of their sexuality (coupled with a refusal to marry someone whom they do not love simply to gain entry to or remain in the United States). Both undocumented and lesbian and gay migrants are potentially legally and epistemologically betwixt and between: in a liminal state in a world where belonging to a nation and having the rights of citizenship are crucial to one's well-being. Undocumented migrants, as well as lesbian and gay [End Page 102] partnerships and marriages, have been incredibly embattled sites for the U.S. culture wars. Historically, sexual minorities have been legally designated as unworthy of legal protections and rights equivalent to those afforded the general populace. Although this form of second-class citizenship is receding albeit slowly, it has served to partially define gay and lesbian people as well as undocumented migrants. Each case challenges human rights at the level of theory and practice to enact the promise made in 1948, to defend what Hannah Arendt (1958) called the sacred and abstract nakedness of being human, without distinction.

The philosophical model of MCC has institutionalized many of the pertinent questions surrounding human rights, lesbian and gay citizenship, and the challenges of border crossing. In addition to being the largest spiritual and religious collective of lesbian and gay people in the world, MCC has built conceptual foundations of social justice and human rights practices corresponding to the complex concerns that arise regarding the migration of binational lesbian and gay couples and individual lesbian and gay people. As a religious institution, MCC may also draw upon its depoliticized legitimacy as a church rather than being perceived as an advocacyoriented organization. The juridical struggles around same-sex marriage and immigration certainly afford space for interventions at the level of Congress, as with the UAFA. But I maintain that moving beyond a purely legalistic approach is also critical. From an advocacy point of view, legal interventions aimed at establishing the rights of sexual minorities are critical — but so, too, are social, cultural, and, perhaps, spiritually based community interventions. In fact, religious or spiritual communities may have networks, tools, and philosophical resources that are better suited to overcoming some of the barriers associated with migration issues for lesbian and gay people and binational same-sex couples.

The case of MCC also allows for a rethinking of the nuclear-family-based, heterosexual model that has been so central to immigration law in the United States. In particular, MCC offers a lens through which to visualize a kind of lesbian and gay collective that is not solely grounded in notions of the family. The concept of a tribal kinship can offer a way to think outside the confines of the family and the household unit. MCC's commitment to a kind of global queer kinship or a lesbian and gay tribal mentality suggests a way of thinking outside the predictable legal avenues of consanguine (blood) and affinal (marital) approaches that determine who shall be allowed or denied immigration access. This variety of queer kinship may use essentialist tropes of immutable difference, but in attempts at reform this approach may be the most realizable.

As Wuen-lin and his partner, Michael, have voiced throughout this article, parishioners and the leadership of MCC have a heartfelt commitment to the institution and the forms of 
community it provides. Although the ideology underlying MCC may be understood as essentialist and politically useful for this very reason, this usefulness does not invalidate the fact that for many, the true appeal of MCC is its phenomenological and spiritual fit, not simply - or even firstly-its political utility. Although the concept of sexual migration serves as an initial and good-to-think-on concept for understanding these dynamics, more research is needed to understand and evaluate both the legal apparatus and the personal dimensions of migration to a new country as a sexual minority, as well as the place and home of sexual-minority migrants within migrant communities or lesbian and gay social networks in the United States.

\section{References}

Agamben, G. (1998). Homo sacer: Sovereign power and bare life (D. Heller-Roazen, Trans.). Stanford, CA: Stanford University Press.

Almaguer, T. (1993). Chicano men: A cartography of homosexual identity and behavior. In H. Abelove, M. A. Barale, \& D. M. Halperin (Eds.), The lesbian and gay studies reader (pp. 255-273). New York: Routledge.

Altman, D. (1973). Homosexual: Oppression and liberation. New York: New York University Press.

Altman, D. (1982). The homosexualization of America, the Americanization of the homosexual. New York: St. Martin's Press.

Arendt, H. (1958). The origins of totalitarianism. New York: Meridian Books.

Argüelles, L., \& Rich, B. R. (1985). Homosexuality, homophobia, and revolution: Notes toward an understanding of the Cuban lesbian and gay male experience, part II. Signs: Journal of Women in Culture and Society, 11, 120-136.

Balfour, I., \& Cadava, E. (2004). The claims of human rights: An introduction. South Atlantic Quarterly, 103, 278-296.

Barta, P. (1998). Lambskin borders: An argument for the abolition of the United States' exclusion of HIV-positive immigrants. Georgetown Immigration Law Journal, 12, 323359.

Berlant, L. (1997). The queen of America goes to Washington City. Durham: Duke University Press.

Bérube, A. (1990). Coming out under fire: The history of gay men and women in World War II. New York: Free Press.

Blackwood, E., \& Wieringa, S. E. (Eds.). (1999). Female desires: Transgender practices across cultures. New York: Columbia University Press.

Boellstorff, T., \& Leap, W. L. (Eds.). (2004). Speaking in queer tongues: Globalization and gay language. Urbana: University of Illinois Press.

Brennan, D. (2004). What's love got to do with it?: Transnational desires and sex tourism in the Dominican Republic. Durham, NC: Duke University Press.

Brown, W. (2004). The most we can hope for: Human rights and the politics of fatalism. South Atlantic Quarterly, 103, 451-463.

Butler, J. (2004). Undoing gender. New York: Routledge.

Cabezas, A. L. (1999). Women's work is never done: Sex tourism in Sosua, the Dominican 
Republic. In K. Kempadoo (Ed.), Sun, sex and gold: Tourism and sex work in the Caribbean (pp. 93-123). Lanham, MD: Rowman \& Littlefield.

Canaday, M. (2003). Who is a homosexual?: The consolidation of sexual identities in midtwentieth-century American immigration law. Law \& Social Inquiry, 28, 351-385.

Cantú, L. (1999). Border crossings: Mexican men and the sexuality of migration. Unpublished doctoral dissertation, University of California, Irvine.

Cantú, L. (2002). De ambiente: Queer tourism and the shifting boundaries of Mexican male sexualities. GLQ: A Journal of Lesbian and Gay Studies, 8, 139-166.

Carrillo, H. (2002). The night is young: Sexuality in Mexico in the time of AIDS. Chicago: University of Chicago Press.

Carrillo, H. (2004). Sexual migration, cross-cultural sexual encounters, and sexual health. Sexuality Research and Social Policy: Journal of NSRC, 1(3), 58-70.

Chauncey, G. (1995). Gay New York: Gender, urban culture, and the making of the gay male world, 1890-1940. New York: Basic Books.

Chinese Exclusion Act of 1882, 47th Cong., Session I, Ch. 126 (1882, May 6) (enacted).

Dank, B. M. (1973). The development of a homosexual identity: Antecedents and consequences. Unpublished doctoral dissertation, University of Wisconsin.

Defense of Marriage Act, 1 U.S.C. $§ 7,28$ U.S.C. $§ 1738 C$ (1996).

D’Emilio, J. (1983). Capitalism and gay identity. In H. Abelove, M. A. Barale, \& D. M. Halperin (Eds.), The lesbian and gay studies reader (pp. 467-476). New York: Routledge.

Donayre, M. (2002). Binational couples: Alliance of fear. The Gay and Lesbian Review Worldwide, 9(2), 25-26.

Espín, O. (1999). Women crossing boundaries: A psychology of immigration and transformations of sexuality. New York: Routledge.

Feher, M. (2000). Powerless by design: The age of the international community. Durham, NC: Duke University Press.

Fernández-Kelly, P. M. (1983). For we are sold, I and my people: Women and industry in Mexico's frontier. Albany: State University of New York.

Gevisser, M., \& Cameron, E. (Eds.). (1995). Defiant desire: Gay and lesbian lives in South Africa. London: Routledge.

González-López, G. (2003). De madres a hijas: Gendered lessons on virginity across generations of Mexican immigrant women. In P. Hondagneu-Sotelo (Ed.), Gender and U.S. migration: Contemporary trends (pp. 217-240). Berkeley: University of California Press.

González-López, G. (2005). Erotic journeys: Mexican immigrants and their sex lives. Berkeley: University of California Press.

Grasmuck, S., \& Pessar, P. R. (1991). Between two islands: Dominican international migration. Berkeley: University of California Press.

Halley, J., \& Brown, W. (Eds.). (1999). Left legalism/left critique. Durham, NC: Duke University Press.

Hondagneu-Sotelo, P. (1994). Gendered transitions: Mexican experiences of immigration. Berkeley: University of California Press.

Howe, C. (2002). Undressing the universal queer subject: Nicaraguan activism and transnational identity. City \& Society, 14, 237-279.

Howe, C. (in press). Erotiscapes: Sex, social justice and Nicaragua's new media era. Durham, NC: Duke University Press.

Hull, K. E. (2003). The cultural power of law and the cultural enactment of legality: The case of 
same-sex marriage. Law \& Social Inquiry, 28, 629-657.

Hutchinson, E. P. (1981). Legislative history of American immigration policy, 1789-1965. Philadelphia: University of Pennsylvania Press.

Ignatieff, M. (2001). Human rights as politics and idolatry. Princeton, NJ: Princeton University Press.

Immigration Equality. (2004, May 11). Brazil clarifies its same-sex immigration policy.

Retrieved February 14, 2007, from Immigration Equality website: http://www.immigrationequality.org/uploadedfiles/ Brazil\%20clarifies\%20samesex\%20immigration\%20policy.pdf

Immigration Equality. (2005). Frequently asked questions about the Uniting American Families Act: How many couples in the U.S. are in binational same sex relationships? Retrieved May 8, 2006, from http://www.immigrationequality.org/template.php?pageid5151

Immigration Equality. (2007). LGBT/HIV asylum manual: Asylum law basics-Brief history of lesbian, gay, bisexual, transgender and HIV (LGBT/H asylum) law. Retrieved March 27, 2007, from http://www.immigrationequality.org/manual_template.php?id51064\#Note_9

Immigration and Nationality Act of 1952, 8 U.S.C. $§ 1151$ (1952).

Indra, D. M. (Ed.). (1999). Engendering forced migration: Theory and practice. New York: Berghahn Books.

Kennedy, E., \& Davis, M. D. (1994). Boots of leather, slippers of gold: The history of a lesbian community. New York: Penguin.

Kinsey, A. C., Pomeroy, W. B., \& Martin, C. E. (1948). Sexual behavior in the human male. New York: W.B. Saunders.

Kinsey, A. C., Pomeroy, W. B., Martin, C. E., \& Gebhard, P. H. (1953). Sexual behavior in the human female. New York: W.B. Saunders.

Lewin, E. (1998). Recognizing ourselves: Ceremonies of lesbian and gay commitment. New York: Columbia University Press.

Loue, S. (1990). Homosexuality and immigration law: A re-examination. Journal of Psychiatry and Law, 18, 109-135.

Love Sees No Borders. (2005). About us. Retrieved February 22, 2007, from http://www.loveseesnoborders.org

Love Sees No Borders. (2007). About us. Retrieved March 2, 2007, from http://www.loveseesnoborders.org

Luibhéid, E., \& Cantú, L., Jr. (Eds.). (2005). Queer migrations: Sexuality, U.S. citizenship and border crossings. Minneapolis: University of Minnesota Press.

Mahler, S. J. (1995). American dreaming. Princeton, NJ: Princeton University Press.

Manalansan, M. F., IV. (1997). In the shadows of Stonewall: Examining gay transnational politics and the diasporic dilemma. In L. Lowe \& D. Lloyd (Eds.), The politics of culture in the shadow of capital (pp. 485-505). Durham, NC: Duke University Press.

Manalansan, M. F., IV. (2003). Global divas: Filipino gay men in the diaspora. Durham, NC: Duke University Press.

Marcuse, H. (1966). Eros and civilization: A philosophical inquiry into Freud. Boston: Beacon Books.

Matter of Toboso-Alfonso. (Board of Immigration Appeals, 1994). 20 I. \& N. Dec. 819 (B.I.A. 1990). Retrieved March 20, 2007, from United States Department of Justice website: http://www.usdoj.gov/eoir/vll/intdec/vol20/3222.pdf

Maupin, A. (1976). Tales of the city. New York: HarperCollins.

McClure, H., Soloway, L., \& Nugent, C. (1997). Preparing sexual orientation-based asylum 
claims: The handbook. Chicago: Heartland Alliance for Human Needs and Human Rights.

Menjívar, C. (2000). Fragmented ties: Salvadoran immigrant networks in America. Berkeley: University of California Press.

Metropolitan Community Church of San Francisco. (1998-2006a). About MCC San Francisco: History. Retrieved February 7, 2007, from http://www.mccsf.org/about/index3.html

Metropolitan Community Church of San Francisco. (1998-2006b). About MCC San Francisco: Mission, vision, values, and goals. Retrieved February 7, 2007, from http://www.mccsf.org/about/index 1.html

Metropolitan Community Churches. (n.d.). Human rights/Social justice. Retrieved June 18, 2006, from http://www.mccchurch.org/AM/Template.cfm?Section=Human_Rights _Social_Justice\&Template=/CM/HTMLDisplay.cfm\&ContentID51318

Metropolitan Community Churches. (2006). MCC marriage equality Valentine's Day 2006:

Resources, activities, and partnerships. Retrieved March 26, 2007, from http://www.mccchurch.org/AM/Template.cfm?Section=Search\&template=/CM/ HTMLDisplay.cfm\&ContentID51316

Nagengast, C., \& Turner, T. (1997). Introduction: Universal human rights versus cultural relativity. Journal of Anthropological Research, 53, 269-272.

Nixon, G. P. (2006). Queer eye for the straight Jesus: Jesus the border crosser [MP3]. San Francisco: Metropolitan Community Church. Retrieved March 25, 2006, from http://www.mccsf.org/worship/special/queereyeresouce.html

Page Law of 1875, 43rd Cong., Session II, Ch. 141 (1875, March 3) (enacted).

Parker, R. (1997). Migration, sexual subcultures, and HIV/AIDS in Brazil. In G. Herdt (Ed.), Sexual cultures and migration in the era of AIDS (pp. 55-69). Oxford, England: Clarendon Press.

Patton, C., \& Sanchez-Eppler, B. (Eds.). (2000). Queer diasporas. Durham, NC: Duke University Press.

Pedraza, S. (1991). Women and migration: The social consequences of gender. Annual Review of Sociology, 17, 303-325.

Perez, G. M. (2004). The near northwest side story: Migration, displacement and Puerto Rican families. Berkeley: University of California Press.

Permanent Partners Immigration Act, S. 1278, $109^{\text {th }}$ Cong. (2005), § 2, "Definitions," $\mid 1$.

Perry, T. D. (1972). The Lord is my shepherd and He knows I'm gay: The autobiography of the Reverend Troy D. Perry. Los Angeles: Nash Publishing.

Perry, T. D., \& Swicegood, T. L. P. (1990). Don't be afraid anymore: The story of Troy Perry and the Metropolitan Community Churches. New York: St. Martin's Press.

Phelan, S. (2001). Sexual strangers: Gays, lesbians and dilemmas of citizenship. Philadelphia: University of Pennsylvania Press.

Portes, A., \& Rumbaut, R. G. (1996). Immigrant America: A portrait. Berkeley: University of California Press.

Ranck, L. (2002). Gays and lesbians in the U.S. immigration process. Peace Review: Journal of Social Justice, 14, 373-377.

Ratti, R. (Ed.). (1993). A lotus of another color: An unfolding of the South Asian gay and lesbian experience. Boston: Alyson Press.

Refugee Act of 1980, Pub. L. No. 96-212 (1980).

Reimers, D. (1992). Still the golden door: The third world comes to America. New York: 
Columbia University Press.

Rofel, L. (1999). Qualities of desire: Imagining gay identity in China. GLQ: A Journal of Lesbian and Gay Studies, 5, 451-474.

Román, D. (2000). Visa denied. In J. A. Boone, M. Dupuis, M. Meeker, K. Quimby, C. Sarver, D. Silverman, et al. (Eds.), Queer frontiers: Millennial geographies, genders, and generations (pp. 350-364). Madison: University of Wisconsin Press.

Sassen, S. (1996). Losing control? Sovereignty in an age of globalization. New York: Columbia University Press.

Seidman, S. (1996). Queer theory/sociology. London: Blackwell.

Sinnott, M. (2004). Toms and dees: Transgender identity and female same-sex relationships in Thailand. Honolulu: University of Hawai'i Press.

Stychin, C. E. (1994). A nation by rights: National cultures, sexual identity politics and the discourse of rights. Philadelphia: Temple University Press.

Sweetman, C. (Ed.). (1998). Gender and migration. Oxford, England: Oxfam Great Britain.

Ungar, M. (2001). Lesbian, gay, bisexual, and transgendered international alliances: The perils of success. In J. M. Bystydzienski \& S. P. Schacht (Eds.), Forging radical alliances across difference: Coalition politics for the new millennium (pp. 235-248). Lanham, MD: Rowman \& Littlefield.

United Nations General Assembly. (1951, July 28). Convention relating to the status of refugees. Article 1(a), § 2, II 1. Retrieved March 20, 2007, from http://www.ohchr.org/english/law/refugees.htm

Uniting American Families Act, H.R. 3006, S. 1278, $110^{\text {th }}$ Cong. (2005).

Universal Declaration of Human Rights. (1948, December 10). United Nations General Assembly Resolution 217 A (III), United Nations Document A 1810 at 71, article 2. Retrieved February 26, 2007, from http://www.un.org/Overview/rights.html

Warner, M. (1993). Fear of a queer planet: Queer politics and social theory. Minneapolis: University of Minnesota Press.

Warner, M. (1999). The trouble with normal: Sex, politics and the ethics of queer life. New York: The Free Press.

Warner, R. S. (1995). The Metropolitan Community Churches and the gay agenda: The power of Pentecostalism and essentialism. Religion and the Social Order, 5, 81-108.

Warner, R. S. (2005). A church of our own: Disestablishment and diversity in American religion. New Brunswick, NJ: Rutgers University Press.

Weston, K. (1991). Families we choose: Lesbians, gays, kinship. New York: Columbia University Press.

Weston, K. (1998). Long slow burn: Sexuality and social science. New York: Routledge.

Wilcox, M. (2003). Coming out in Christianity: Religion, identity and community. Bloomington: University of Indiana Press.

Wilson, N. (1995). Our tribe: Queer folks, God, Jesus, and the Bible. San Francisco: Harper Collins.

žižek, S. (2005). Against human rights. New Left Review, 34, 115-131. 